\title{
High ambient radiofrequency radiation in Stockholm city, Sweden
}

\author{
MICHAEL CARLBERG ${ }^{1,2}$, LENA HEDENDAHL $^{2}$, TARMO KOPPEL $^{3}$ and LENNART HARDELL LEL $^{1,2}$ \\ ${ }^{1}$ Department of Oncology, Faculty of Medicine and Health, Örebro University, \\ SE 70182 Örebro; ${ }^{2}$ The Environment and Cancer Research Foundation, SE 70217 Örebro, Sweden; \\ ${ }^{3}$ Department of Labour Environment and Safety, Tallinn University of Technology, Tallinn 19086, Estonia
}

Received July 13, 2018; Accepted October 31, 2018

DOI: $10.3892 / \mathrm{ol} .2018 .9789$

\begin{abstract}
We measured the radiofrequency (RF) radiation at central parts in Stockholm, Sweden in March and April 2017. The same measurement round tour was used each time. We used EME Spy 200 for the measurements as in our previous studies in Stockholm. The results were based on 11,482 entries, corresponding to more than $12 \mathrm{~h}$ measurements. The total mean level was 5,494 $\mu \mathrm{W} / \mathrm{m}^{2}$ (median 3,346; range 36.6-205,155). The major contributions were down links from LTE 800 (4G), GSM + UMTS 900 (3G), GSM 1800 (2G), UMTS 2100 (3G) and LTE 2600 (4G). Regarding different places, the highest RF radiation was measured at the Hay Market with a mean level of $10,728 \mu \mathrm{W} / \mathrm{m}^{2}$ (median 8,578 ; range $335-68,815$ ). This is a square used for shopping, and both retailers and visitors may spend considerable time at this place. Also, the Sergel Plaza had high radiation with a mean of $7,768 \mu \mathrm{W} / \mathrm{m}^{2}$. All measurements exceeded the target level of $30-60 \mu \mathrm{W} / \mathrm{m}^{2}$ based on non-thermal (no heating) effects, according to the BioInitiative Report. Based on short-term thermal effects, The International Commission on Non-Ionizing Radiation Protection established guideline 2 of $10 \mathrm{~W} / \mathrm{m}^{2}\left(2,000,000-10,000,000 \mu \mathrm{W} / \mathrm{m}^{2}\right)$ depending on frequency in 1998, and has not changed it despite solid evidence of non-thermal biological effects at substantially lower exposure levels. These environmental RF radiation levels are expected to increase with the introduction of $5 \mathrm{G}$ for wireless communication.
\end{abstract}

\section{Introduction}

Our research team has during the recent years made measurements of radiofrequency (RF) radiation at the Central Station (1), in the Old Town (2), and in a private apartment (3) in Stockholm, Sweden. We found high levels in certain places such as a square (Järntorget) in the Old Town with nearby base stations. Also, in the apartment high levels were measured due

Correspondence to: Professor Lennart Hardell, The Environment and Cancer Research Foundation, 35 Studievägen, SE 70217 Örebro, Sweden

E-mail: lennart.hardell@environmentandcancer.com

Key words: radiofrequency radiation, microwaves, measurement, base stations, exposure, health, cancer, Stockholm city to the proximity to base stations. In contrast we measured low levels in parts of the WHO office in Geneva, Switzerland (4). We now report the results of measurements in Stockholm city performed in March and April 2017.

These results give an estimate of RF radiation levels before the introduction of the fifth generation, $5 \mathrm{G}$, for wireless communication. During the time for all these measurements no $5 \mathrm{G}$ was implemented. Despite an EU appeal by more than 200 scientists and medical doctors asking for a moratorium on the introduction of $5 \mathrm{G}$ until further independent research on consequences on health and environment are performed, there seems to be no plans to halt the building of that network (5). In addition, the animal studies by the National Toxicology Program (NTP) in USA (6-8) and the Ramazzini Institute in Italy (9) have recently provided additional evidence on the carcinogenicity of RF radiation.

Apart from the cancer risk from exposure to RF radiation, several studies show other possible adverse health effects in inhabitants living near mobile base station. Symptoms like headache, fatigue, dizziness, sleep disturbances, cardiovascular symptoms, depression and difficulties with concentration and memory have been reported (10-15). A study in Rimbach, Germany, showed adverse effects on the neurotransmitters adrenalin, noradrenalin, dopamin and phenyletylamine after a GSM mobile base station was activated 2004 (16). Hormone profiles were measured in volunteers living near a mobile base station. Serum cortisol, plasma ACTH and thyroid hormones decreased statistically significantly. Prolactin in young women and testosterone in men also decreased during the study time of up to six years (17). Two different studies from India showed that persons who lived near mobile phone base stations had higher frequency of micronuclei, lowered antioxidant levels and induced DNA damage in their blood lymphocytes $(18,19)$. Also lowered levels of stimulated salivary secretion and more health complaints have been seen (15) and an increase of salivary cortisol after exposure to RF radiation from mobile phone base stations has been reported (20).

A biological mechanism for exposure to RF radiation and possible harmful effects can be the stimulation of oxidative stress. A study showed lower values of antioxidant levels and a higher mean level of lipid peroxidation assay as a sign for increased free radicals in a study population living near mobile phone base stations (21). Free radicals may play an important role in many diseases such as cancer and cardiovascular, immunological and endocrine diseases (21). A spatial 
correlation between mortality in cancer and distance to a mobile phone base station was found in a study in Brazil (22). Also in a review, 2 of 3 studies showed augmented cancer incidence for people living near mobile base stations (23).

This study forms part of our on-going measurements of $\mathrm{RF}$ radiation in public places. Of special interest is places with many visitors but also including areas with persons working for several hours per day. This was a measurement study with no involvement of test persons. Thus, no ethical permission was needed.

\section{Materials and methods}

EME Spy 200 Exposimeter. In this study an EME Spy 200 exposimeter with a valid calibration was used to collect the exposure data. Axial isotropy is from \pm 1 to $\pm 2.8 \mathrm{~dB}$ depending on the frequency band. The measurement accuracy is very good relative to this type of measurements and the measurement errors are not biologically significant. The exposimeter measures 20 predefined frequency bands as presented in Table I. They cover the frequencies of most public RF radiation emitting devices currently used in Sweden. The exposimeter covers frequencies from 88 to $5,850 \mathrm{MHz}$. For FM, TV3, TETRA, TV4\&5, $\mathrm{Wi}-\mathrm{Fi} 2 \mathrm{G}$ and $\mathrm{Wi}-\mathrm{Fi} 5 \mathrm{G}$ the lower detection limit is $0.01 \mathrm{~V} / \mathrm{m}$ $\left(0.27 \mu \mathrm{W} / \mathrm{m}^{2}\right)$; for all other bands the lower detection limit is $0.005 \mathrm{~V} / \mathrm{m}\left(0.066 \mu \mathrm{W} / \mathrm{m}^{2}\right)$. For all bands the upper detection limit is $6 \mathrm{~V} / \mathrm{m}\left(95,544 \mu \mathrm{W} / \mathrm{m}^{2} ; 9.5544 \mu \mathrm{W} / \mathrm{cm}^{2}\right)$. The sampling time used in this study was every fourth second which is the fastest for the given exposimeter.

The exposimeter measures different telecommunications protocols: FM (frequency modulation) radio broadcasting; TV (television) broadcasting; TETRA emergency services (police, rescue, etc.); GSM (global system for mobile communications) second generation mobile communications; UMTS (universal mobile telecommunications systems) third generation mobile communications, 3G; LTE (long term evolution) fourth generation mobile communications standard, 4G; DECT (digital European cordless telecommunications) cordless telephone systems standard; Wi-Fi wireless local area network protocol; WIMAX (worldwide interoperability for microwave access) wireless communication standard for high speed voice, data and Internet.

EME SPY 200 utilizes 3-axis antennas to capture RF radiation from all possible directions and polarizations. The exposimeter was held at some distance (approximately 0.4 meters) from the body. The unit reports the exposure in a conservative manner since each reported value is the sampling outcome, where many samples are taken and statistically processed including minimum, mean, median and maximum values.

Study design. All measurements were performed during March and April 2017. Each measurement tour started at Stureplan, Stockholm that is a common place for visitors, see Fig. 1. It always followed the same route via Norrmalmstorg plaza to Sergel Plaza. From there streets passing the Central Railway station and Rosenbad, the administrative center for the Government, and further via the main street Drottninggatan ending at the Hay Market, a place for outdoor shopping, were used. Finally, Kungsgatan was measured ending at Stureplan again. The measurement rounds were conducted on a steady pace, keeping a constant speed. In order to spatially represent the mean RF exposure levels, the squares were covered by spiral movement pattern, covering the space by evenly distributed layout. The measurement rounds covered the major public hotspots, hence we consider the route to be representative of a public exposure in this city. In total measurements were made during five different days.

Statistical methods. Means in $\mu \mathrm{W} / \mathrm{m}^{2}$ were calculated for all measured frequency bands and a box plot was constructed to illustrate the distribution of total exposure for all measurement locations. Values at lower detection limit were treated as no (0) exposure. Total exposure was calculated as the sum of all measured frequency bands. Stata/SE 12.1 (Stata/SE 12.1 for Windows; StataCorp., College Station, TX, USA) was used for all calculations.

\section{Results}

Total round. The results were based on 11,482 entries in total corresponding to more than $12 \mathrm{~h}$ of measurements, see Table II. The total mean level was $5,494 \mu \mathrm{W} / \mathrm{m}^{2}$ (median 3,346, range 36.6-205,155). The major contributions were from down links (DL) from LTE 800 (4G), GSM + UMTS 900 (3G), GSM 1800 (2G), UMTS 2100 (3G), and LTE 2600 (4G), see Table II. If all down links were excluded from the measurements the mean level dropped to $118 \mu \mathrm{W} / \mathrm{m}^{2}$ (median 36.0, range 0-9,157).

The Hay Market. As shown in Table III and Fig. 2 the highest RF-radiation was measured at the Hay Market with mean level $10,728 \mu \mathrm{W} / \mathrm{m}^{2}$ and median $8,578 \mu \mathrm{W} / \mathrm{m}^{2}$. These results were based on 1,202 entries, see Table IV. LTE 2600 DL showed the highest mean level, 3,697 $\mu \mathrm{W} / \mathrm{m}^{2}$. There was a large variability in signal strength during the measurements ranging from 335 to $68,815 \mu \mathrm{W} / \mathrm{m}^{2}$ with high mean and average values, see Fig. 3 .

The Sergel Plaza. Also the Sergel Plaza had a high mean level, $7,768 \mu \mathrm{W} / \mathrm{m}^{2}$ (median 6,466, range 66.6-50,897), Table III and Fig. 2. Table V shows the contribution of different frequencies. Also here LTE 2600 DL (4G) gave the highest level.

\section{Discussion}

As shown in Fig. 1 the same pathway was used each time. The 11,482 recordings corresponded to more than $12 \mathrm{~h}$ of measurements. The total mean level was $5,494 \mu \mathrm{W} / \mathrm{m}^{2}$ (median 3,346, range $36.6-205,155)$. These results may be compared with our previous measurements.

We made our first measurements with the EME Spy 200 Exposimeter at the Stockholm Central Station in November 2015 (1). The results were based on 1,669 entries and yielded mean total $\mathrm{RF}$ radiation level $3,860 \mu \mathrm{W} / \mathrm{m}^{2}$ (median 921, range 5.8-155,263).

The next measurement included Stockholm Old Town in April 2016 (2). The results were based on 10,437 samples in total. The mean level of total RF-radiation was $4,293 \mu \mathrm{W} / \mathrm{m}^{2}$ (median 534, range 0-173,302).

We measured levels of RF-radiation in an apartment located at Östermalm, Stockholm. The results were based on 
Table I. Predefined measurement frequency bands of EME Spy 200 Exposimeter. Frequency ranges.

\begin{tabular}{|c|c|c|}
\hline Frequency band & $\begin{array}{l}\text { Frequency } \\
\text { Min, } \mathrm{MHz}\end{array}$ & $\begin{array}{l}\text { Frequency } \\
\mathrm{Max}, \mathrm{MHz}\end{array}$ \\
\hline FM & 88 & 107 \\
\hline TV3 & 174 & 223 \\
\hline TETRA I & 380 & 400 \\
\hline TETRA II & 410 & 430 \\
\hline TETRA III & 450 & 470 \\
\hline TV4 and 5 & 470 & 770 \\
\hline LTE $800,4 \mathrm{G}\left(\mathrm{DL}^{\mathrm{a}}\right)$ & 791 & 821 \\
\hline LTE $800,4 \mathrm{G}\left(\mathrm{UL}^{\mathrm{b}}\right)$ & 832 & 862 \\
\hline $\begin{array}{l}\text { GSM 900+ UMTS 900, } \\
3 \mathrm{G} \text { (UL) }\end{array}$ & 880 & 915 \\
\hline $\begin{array}{l}\text { GSM 900+ UMTS 900, } \\
\text { 3G (DL) }\end{array}$ & 925 & 960 \\
\hline GSM 1800 (UL) & 1,710 & 1,785 \\
\hline GSM 1800 (DL) & 1,805 & 1,880 \\
\hline DECT & 1,880 & 1,900 \\
\hline UMTS 2100, 3G (UL) & 1,920 & 1,980 \\
\hline UMTS $2100,3 \mathrm{G}$ (DL) & 2,110 & 2,170 \\
\hline Wi-Fi, 2 GHz & 2,400 & $2,483.5$ \\
\hline LTE 2600, 4G (UL) & 2,500 & 2,570 \\
\hline LTE 2600, 4G (DL) & 2,620 & 2,690 \\
\hline WiMax & 3,300 & 3,900 \\
\hline Wi-Fi $5 \mathrm{GHz}$ & 5,150 & 5,850 \\
\hline
\end{tabular}

${ }^{\mathrm{a}}$ Transmission from base station to mobile phone; ${ }^{\mathrm{b}}$ Transmission from mobile phone to base station. FM, frequency modulation; TV, television; LTE, long-term evolution; DL, downlink (transmission from base station to mobile phone); UL, uplink (transmission from mobile phone to base station); GSM, global system for mobile communications; UMTS, universal mobile telecommunications system; DECT, digital European cordless telecommunications; WiMAX, worldwide interoperability for microwave access.

74,531 entries for 6 different tours in June and August 2017 Also, balconies were measured (3). The study was initiated by concern of RF radiation from nearby base stations on the top of roofs. The mean RF radiation level was $3,811 \mu \mathrm{W} / \mathrm{m}^{2}$ (median 1,313, range 15.2-112,318). Highest RF radiation level was obtained at a balcony outside the living room with mean value $24,886 \mu \mathrm{W} / \mathrm{m}^{2}$ (median 22,256, range $72.0-112,318$ ). As we discussed in the article these levels of RF radiation are not compatible with long-time living in the apartment, especially not for children.

The aim of this article is not to discuss in more detail results from measurements of RF radiation levels in other countries. For a more comprehensive review see our previous publications (1-4). In these publications we discuss also health risks and other biological effects from RF radiation. The levels in the present study are among the highest that we have measured in Stockholm so far. Obviously, they exceed the scientific benchmark on $30-60 \mu \mathrm{W} / \mathrm{m}^{2}$ for potential health risks based on non-thermal effects as published in the BioInitiative
Table II. Stockholm city levels of radiofrequency radiation based on 11,482 entries, measurements 20170305-20170307, 20170413 and 20170416 . Analysis of all data $\left(\mu \mathrm{W} / \mathrm{m}^{2}\right)$ treating values at detection limit as 0 .

\begin{tabular}{|c|c|c|c|c|}
\hline Frequency band & Mean & Median & Min & Max \\
\hline FM & 3.6 & 0.0 & 0.0 & $4,224.5$ \\
\hline TV3 & 0.6 & 0.0 & 0.0 & 317.5 \\
\hline TETRA I & 2.3 & 0.0 & 0.0 & $2,096.3$ \\
\hline TETRA II & 1.4 & 0.0 & 0.0 & 554.0 \\
\hline TETRA III & 0.1 & 0.0 & 0.0 & 124.9 \\
\hline TV4 and 5 & 6.3 & 0.0 & 0.0 & $6,672.1$ \\
\hline LTE 800 (DL) & 750.9 & 243.5 & 0.8 & $80,034.6$ \\
\hline LTE 800 (UL) & 0.0 & 0.0 & 0.0 & 4.0 \\
\hline $\begin{array}{l}\text { GSM + UMTS } \\
900 \text { (UL) }\end{array}$ & 0.1 & 0.0 & 0.0 & 299.5 \\
\hline $\begin{array}{l}\text { GSM + UMTS } \\
900 \text { (DL) }\end{array}$ & $1,169.5$ & 583.5 & 2.2 & $95,522.5$ \\
\hline GSM 1800 (UL) & 12.3 & 2.2 & 0.0 & $2,620.8$ \\
\hline GSM 1800 (DL) & 465.0 & 189.1 & 1.9 & $44,393.3$ \\
\hline DECT & 59.0 & 0.7 & 0.0 & $6,714.3$ \\
\hline UMTS 2100 (UL) & 0.0 & 0.0 & 0.0 & 10.5 \\
\hline UMTS 2100 (DL) & $1,211.5$ & 598.5 & 5.9 & $43,852.4$ \\
\hline WIFI $2 \mathrm{G}$ & 0.3 & 0.0 & 0.0 & 616.2 \\
\hline LTE 2600 (UL) & 32.1 & 5.1 & 0.0 & $3,762.5$ \\
\hline LTE 2600 (DL) & $1,779.1$ & 846.8 & 4.0 & $40,572.7$ \\
\hline WIMax & 0.0 & 0.0 & 0.0 & 0.8 \\
\hline WIFI 5G & 0.1 & 0.0 & 0.0 & 88.8 \\
\hline Total & $5,494.2$ & $3,346.0$ & 36.6 & $205,154.8$ \\
\hline
\end{tabular}

FM, frequency modulation; TV, television; LTE, long-term evolution; DL, downlink (transmission from base station to mobile phone); UL, uplink (transmission from mobile phone to base station); GSM, global system for mobile communications; UMTS, universal mobile telecommunications system; DECT, digital European cordless telecommunications; WiMAX, worldwide interoperability for microwave access.

Report (24). Based on chronic exposure an even lower level, 3-6 $\mu \mathrm{W} / \mathrm{m}^{2}$, with safety factor 10 was suggested for sensitive groups including children.

In contrast, the International Commission on Non-Ionizing Radiation Protection (ICNIRP) based their target level on short-term (acute) exposure. It was established in 1998 (25) and updated in 2009 (26) without any change of the guideline 2 to $10 \mathrm{~W} / \mathrm{m}^{2}\left(2,000,000\right.$ to $\left.10,000,000 \mu \mathrm{W} / \mathrm{m}^{2}\right)$ depending of frequency. Despite being outdated, considering only thermal effects, and not based on current knowledge, the ICNIRP guideline is used in many countries such as by the Swedish Radiation Safety Authority (SSM).

Most areas in our current study are only used by people when passing by. Thus, the high involuntary exposure is for a short time. However, some of the streets are popular for visitors, those going for shopping or strolling along the street just for pleasure. This might give more extended exposure. One contrast is the Hay Market. This is popular place for marketing 
Table III. Stockholm city total levels of radiofrequency radiation for different locations, measurements 20170305-20170307, 20170413 and 20170416. Analysis of all data $\left(\mu \mathrm{W} / \mathrm{m}^{2}\right)$ treating values at detection limit as 0.

\begin{tabular}{lrrrrr}
\hline Location & $\mathrm{n}$ & Mean & Median & Min & Max \\
\hline Stureplan & 696 & $2,664.7$ & $1,816.0$ & 158.9 & $33,678.6$ \\
Biblioteksgatan, Norrmalmstorg, Hamngatan & 2,473 & $5,000.4$ & $3,477.9$ & 36.6 & $53,681.2$ \\
Sergel plaza & 1,651 & $7,767.6$ & $6,466.5$ & 66.6 & $50,897.3$ \\
Klarabergsgatan, Vasagatan, Tegelbacken, & 2,136 & $3,790.8$ & $1,934.6$ & 37.1 & $77,451.6$ \\
Rosenbad, Strömgatan to Drottninggatan & & & & & \\
Drottninggatan to Kungsgatan & 1,661 & $4,257.4$ & $2,708.3$ & 132.6 & $205,154.8$ \\
Kungsgatan & 1,663 & $4,795.4$ & $2,610.7$ & 66.7 & $61,053.6$ \\
Hay market & 1,202 & $10,728.5$ & $8,577.7$ & 335.4 & $68,814.6$ \\
Total & 11,482 & $5,494.2$ & $3,346.0$ & 36.6 & $205,154.8$ \\
\hline
\end{tabular}

Table IV. Hay Market, Stockholm, levels of radiofrequency radiation in total based on 1,202 entries. Analysis of all data $\left(\mu \mathrm{W} / \mathrm{m}^{2}\right)$ treating values at detection limit as 0 .

\begin{tabular}{|c|c|c|c|c|}
\hline Frequency band & Mean & Median & Min & Max \\
\hline FM & 1.6 & 0.0 & 0.0 & 407.6 \\
\hline TV3 & 0.8 & 0.0 & 0.0 & 154.1 \\
\hline TETRA I & 1.1 & 0.0 & 0.0 & $1,244.6$ \\
\hline TETRA II & 0.1 & 0.0 & 0.0 & 16.6 \\
\hline TETRA III & 0.0 & 0.0 & 0.0 & 1.0 \\
\hline TV4 and 5 & 8.0 & 0.0 & 0.0 & 551.6 \\
\hline LTE 800 (DL) & $1,081.8$ & 495.0 & 26.5 & $30,771.4$ \\
\hline LTE 800 (UL) & 0.0 & 0.0 & 0.0 & 0.1 \\
\hline $\begin{array}{l}\text { GSM + UMTS } \\
900 \text { (UL) }\end{array}$ & 0.0 & 0.0 & 0.0 & 25.5 \\
\hline $\begin{array}{l}\text { GSM + UMTS } \\
900 \text { (DL) }\end{array}$ & $2,063.0$ & $1,192.5$ & 66.2 & $21,802.9$ \\
\hline GSM 1800 (UL) & 15.3 & 3.2 & 0.0 & $1,120.7$ \\
\hline GSM 1800 (DL) & 991.0 & 609.9 & 17.4 & $34,740.5$ \\
\hline DECT & 95.2 & 14.3 & 0.0 & $3,756.2$ \\
\hline UMTS 2100 (UL) & 0.0 & 0.0 & 0.0 & 10.5 \\
\hline UMTS 2100 (DL) & $2,725.9$ & $1,354.1$ & 32.7 & $43,852.4$ \\
\hline WIFI 2G & 0.2 & 0.0 & 0.0 & 27.1 \\
\hline LTE 2600 (UL) & 47.3 & 8.0 & 0.0 & $2,373.8$ \\
\hline LTE 2600 (DL) & $3,697.1$ & $2,401.5$ & 43.5 & $38,929.9$ \\
\hline WIMax & 0.0 & 0.0 & 0.0 & 0.3 \\
\hline WIFI 5G & 0.1 & 0.0 & 0.0 & 11.6 \\
\hline Total & $10,728.5$ & $8,577.7$ & 335.4 & $68,814.6$ \\
\hline $\begin{array}{l}\text { UL, uplink (transmi } \\
\text { global system for } \mathrm{m} \\
\text { telecommunications } \\
\text { telecommunications } \\
\text { wave access. }\end{array}$ & $\begin{array}{l}\text { on; TV, } \\
\text { mission } \\
\text { from } n \\
\text { comm }\end{array}$ & $\begin{array}{l}\text { ision; } \\
\text { base s } \\
\text { phone } \\
\text { ions; U }\end{array}$ & dSS & $\begin{array}{l}\text { m evolu- } \\
\text { e phone); } \\
\text { n); GSM, } \\
\text { al mobile } \\
\text { cordless }\end{array}$ \\
\hline
\end{tabular}

of flowers, fruits, berries, etc. Thus, the dealers may during the whole day be exposed to high RF radiation. The mean level
Table V. Sergel Plaza, Stockholm, levels of radiofrequency radiation in total based on 1,651 entries. Analysis of all data $\left(\mu \mathrm{W} / \mathrm{m}^{2}\right)$ treating values at detection limit as 0 .

\begin{tabular}{lrrrr}
\hline Frequency band & Mean & Median & Min & \multicolumn{1}{c}{ Max } \\
\hline FM & 1.7 & 0.0 & 0.0 & 281.9 \\
TV3 & 1.5 & 0.0 & 0.0 & 268.2 \\
TETRA I & 4.1 & 0.0 & 0.0 & 146.5 \\
TETRA II & 0.5 & 0.0 & 0.0 & 183.5 \\
TETRA III & 0.0 & 0.0 & 0.0 & 5.4 \\
TV4 and 5 & 7.1 & 0.0 & 0.0 & $1,966.4$ \\
LTE 800 (DL) & $1,047.2$ & 450.2 & 2.2 & $23,052.3$ \\
LTE 800 (UL) & 0.0 & 0.0 & 0.0 & 0.2 \\
GSM + UMTS & 0.6 & 0.0 & 0.0 & 299.5 \\
900 (UL) & & & & \\
GSM + UMTS & $1,400.8$ & 904.7 & 4.9 & $24,449.1$ \\
900 (DL) & & & & \\
GSM 1800 (UL) & 15.2 & 1.1 & 0.0 & $1,871.6$ \\
GSM 1800 (DL) & 647.9 & 273.3 & 2.5 & $35,746.0$ \\
DECT & 133.0 & 19.2 & 0.0 & $6,104.2$ \\
UMTS 2100 (UL) & 0.0 & 0.0 & 0.0 & 3.4 \\
UMTS 2100 (DL) & $1,944.3$ & $1,378.9$ & 10.9 & $35,029.1$ \\
WIFI 2G & 0.1 & 0.0 & 0.0 & 14.1 \\
LTE 2600 (UL) & 26.4 & 8.0 & 0.0 & $1,371.2$ \\
LTE 2600 (DL) & $2,537.1$ & $1,894.0$ & 6.6 & $21,726.9$ \\
WIMax & 0.0 & 0.0 & 0.0 & 0.4 \\
WIFI 5G & 0.1 & 0.0 & 0.0 & 13.0 \\
Total & $7,767.6$ & $6,466.5$ & 66.6 & $50,897.3$ \\
\hline
\end{tabular}

FM, frequency modulation; TV, television; LTE, long-term evolution; DL, downlink (transmission from base station to mobile phone); UL, uplink (transmission from mobile phone to base station); GSM, global system for mobile communications; UMTS, universal mobile telecommunications system; DECT, digital European cordless telecommunications; WiMAX, worldwide interoperability for microwave access.

was $10,728 \mu \mathrm{W} / \mathrm{m}^{2}$ which exceeds very much levels known to have biological effects. 


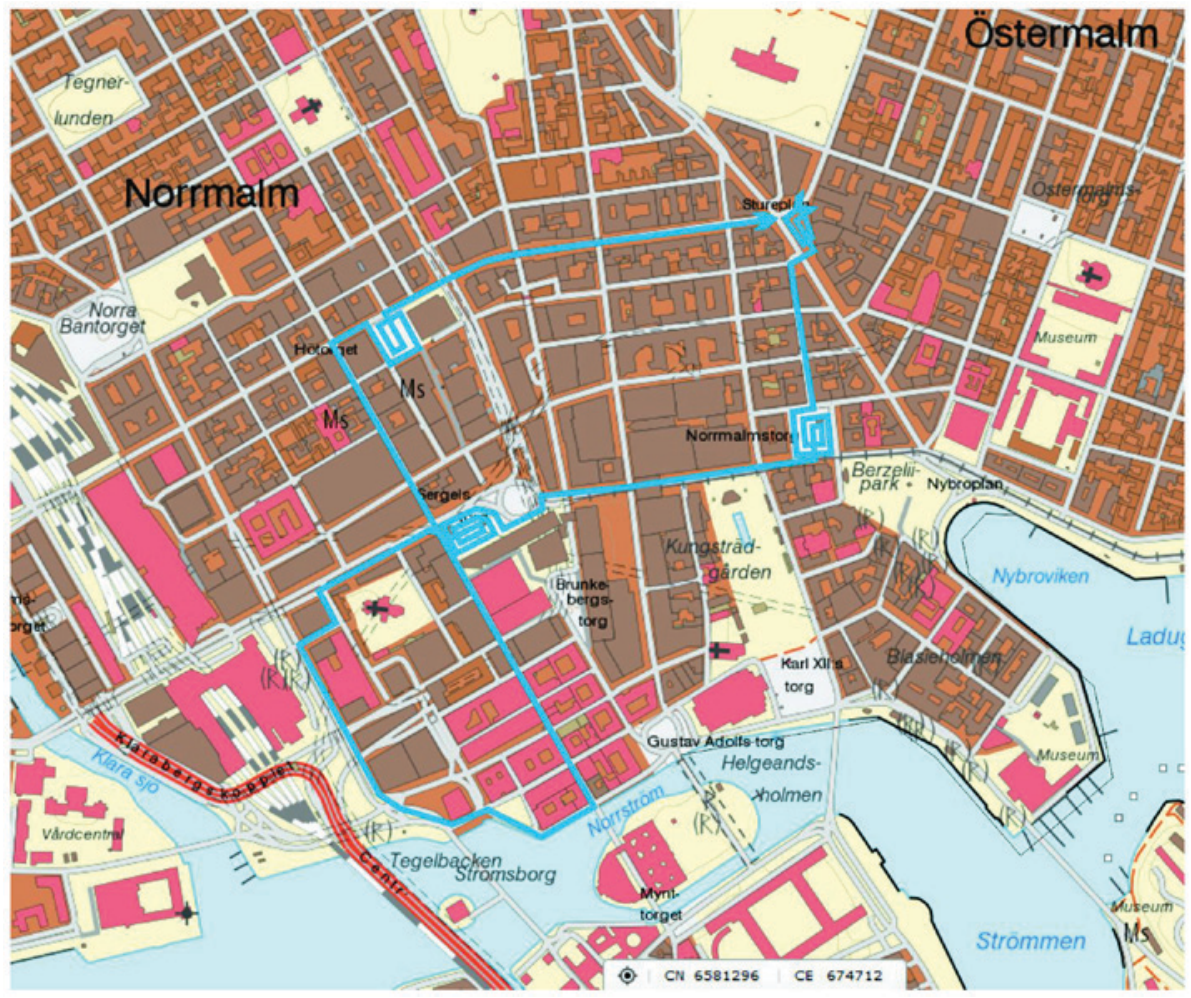

Figure 1 . Stockholm city measurement tour, marked by blue; map by Lantmäteriet, Sweden.

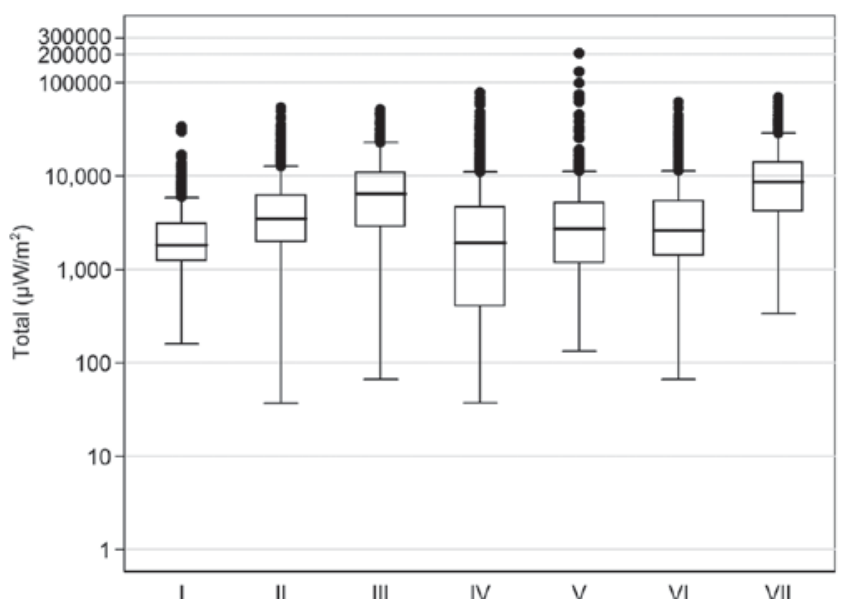

Figure 2. Box plot of total exposure in $\mu \mathrm{W} / \mathrm{m}^{2}$, logarithmic scale, measurements 20170305-20170307, 20170413 and 20170416 in Stockholm city. The median is indicated by a black line inside each box; the bottom and top of the boxes show first and third quartiles; the end of the whiskers are calculated as $1.5 x$ interquartile range. Points represent outliers. I, Stureplan; II, Biblioteksgatan, Norrmalmstorg, Hamngatan; III, Sergel Plaza; IV, Klarabergsgatan, Vasagatan, Tegelbacken, Rosenbad, Strömgatan to Drottninggatan; V, Drottninggatan to Kungsgatan; VI, Kungsgatan; VII, Hay Market.

The results of this study point out unnecessarily high $\mathrm{RF}$ radiation areas in several parts of Stockholm city. Using high-power levels causes an excess health risk to many people. Even higher RF radiation is expected when $5 \mathrm{G}$ is implemented.

$5 \mathrm{G}$ will use several different frequencies. According to The Swedish 'Post and Telestyrelsen' (The Swedish Post and Telecom Authority, PTS) the plan for $5 \mathrm{G}$ in Sweden is in the bands of $700 \mathrm{MHZ}, 3.4-3.6 \mathrm{GHz}$ and 26.5-27.5 GHz. These

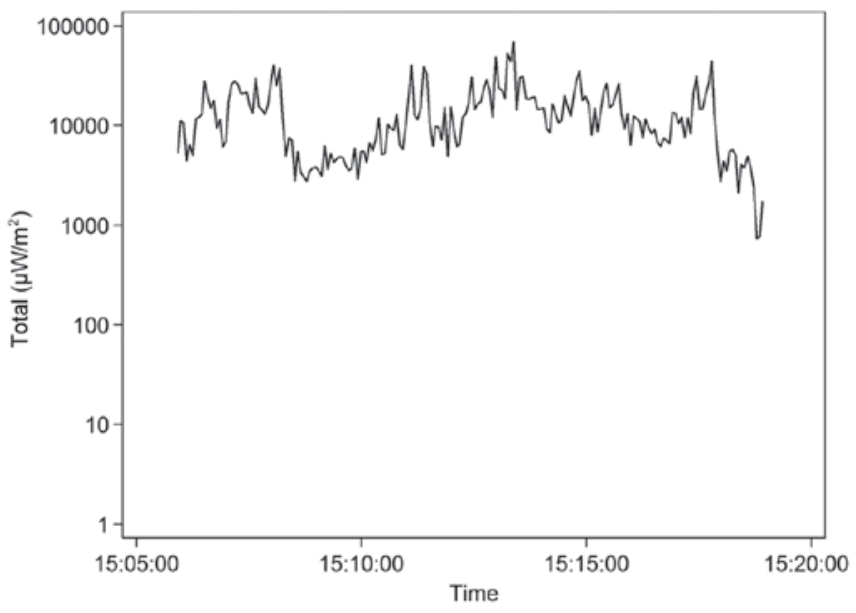

Figure 3. Time variation of measurement at the Hay Market 20170416 $\left(\mu \mathrm{W} / \mathrm{m}^{2}\right.$ on a logarithmic scale; total mean exposure $13,763.8 \mu \mathrm{W} / \mathrm{m}^{2}$ in this measurement).

frequency have wavelengths of $428.6 \mathrm{~mm}, 88.2-83.3 \mathrm{~mm}$ and 11.3-10.9 mm, respectively. Super high frequencies, like 26.5-27.5 GHz have wavelengths in the millimeter scale, and are named millimeter waves (MMW). Millimeter waves have low penetration depth into the body. Primarily skin and ocular effects have been seen. MMW may have effects on nerve endings and capillaries in the skin and through them influence deeper structures and functions in the body $(27,28)$. Sweat ducts in the skin may act as helical antennas and respond to MMW for penetration (29,30). MMW can also have effects on bacterial growth and augmented antibiotic resistance (31), which can lead to difficulties to treat severe infections. 
$\mathrm{RF}$ radiation from mobile phone base station expose the environment day and night. Long duration of exposure to RF radiation can be an important factor in adverse health effects even with exposure at lower power densities $(32,33)$. There can also be a significant difference in sensibility to RF radiation between individuals (34). It seems that RF radiation from mobile phone base stations, mobile phones, wireless networks, smart meters and all other wireless devices can have adverse health effects and lead to neurobehavioral, hormonal and immunological effects and cancer (35).

The introduction of $5 \mathrm{G}$ will augment the total exposure and also the total amount of different frequencies that will expose the population. The total incidence of cancer is increasing in Sweden and daily papers often report about sleep disturbances, pain problems, burned-out syndromes, depression and more people on sick-leaves. There can be several different causes for this increase in ill health, but the population has never before been exposed to this amount of $\mathrm{RF}$ radiation. It does not seem to halt even with these levels of exposure since mobile phone industries and governments want to progress toward an even more digital and wireless world. More research is urgently needed to evaluate the exposure levels we already have and their possible medical consequences and the exposure levels we will get when $5 \mathrm{G}$ is implemented, see e.g. the 5G Appeal (5).

\section{Acknowledgements}

Not applicable.

\section{Funding}

The present study was supported by grants from Mr. Brian Stein, Cancer-och Allergifonden, Cancerhjälpen and the Pandora-Foundation for Independent Research, Berlin, Germany.

\section{Availability of data and materials}

The datasets generated and analyzed during the current study are available from the corresponding author on reasonable request.

\section{Authors' contributions}

LHa and TK collected all the measurements. MC performed the statistical calculations, LHe contributed with the review of medical aspects from mobile phone base station studies and TK was responsible for technical and methodological aspects of the study. All authors participated in the writing of the manuscript, and have read and approved the final version of the manuscript.

\section{Ethics approval and consent to participate}

Not applicable.

\section{Patient consent for publication}

Not applicable.

\section{Competing interests}

The authors declare that they have no competing interests.

\section{References}

1. Hardell L, Koppel T, Carlberg M, Ahonen M and Hedendahl L: Radiofrequency radiation at Stockholm Central Railway Station in Sweden and some medical aspects on public exposure to RF fields. Int J Oncol 49: 1315-1324, 2016.

2. Hardell L, Carlberg M, Koppel T and Hedendahl L: High radiofrequency radiation at Stockholm Old Town: An exposimeter study including the Royal Castle, Supreme Court, three major squares and the Swedish Parliament. Mol Clin Oncol 6: 462-476, 2017.

3. Hardell L, Carlberg M and Hedendahl LK: Radiofrequency radiation from nearby base stations gives high levels in an apartment in Stockholm, Sweden: A case report. Oncol Lett 15: 7871-7883, 2018.

4. Hardell L: World Health Organization, radiofrequency radiation and health-a hard nut to crack (Review). Int J Oncol 51: 405-413, 2017.

5. The 5G appeal: Scientists and doctors warn of potential serious health effects of 5G. http://www.5gappeal.eu/scientistsand-doctors-warn-of-potential-serious-health-effects-of- $5 \mathrm{~g} /$. Accessed July 4, 2018.

6. Wyde M, Cesta M, Blystone C, Bucher J, Elmore S, Foster P, Hooth M, Kissling G, Malarkey D, Sills R, et al: Report of partial findings from the National Toxicology Program Carcinogenesis Studies of Cell Phone Radiofrequency Radiation in Hsd: Sprague Dawley ${ }^{\circledR} \mathrm{SD}$ rats (Whole Body Exposures). http://biorxiv. org/content/biorxiv/early/2016/05/26/055699.full.pdf. Accessed July 11, 2018.

7. National Toxicology Program: NTP technical report on the toxicology and carcinogenesis studies in Hsd:Sprague Dawley sd rats exposed to whole-body radio frequency radiation at a frequency $(900 \mathrm{MHz})$ and modulations (GSM and CDMA) used by cell phones. NTP TR 595, March 26-28, 2018. https://ntp. niehs.nih.gov/ntp/about_ntp/trpanel/2018/march/tr595peerdraft. pdf. Accessed July 11, 2018.

8. National Toxicology Program: NTP technical report on the toxicology and carcinogenesis studies in $\mathrm{B} 6 \mathrm{C} 3 \mathrm{~F} 1 / \mathrm{N}$ mice exposed to whole-body radio frequency radiation at a frequency $(1,900 \mathrm{MHz})$ and modulations (GSM and CDMA) used by cell phones. NTP TR 596, March 26-28, 2018. https://ntp.niehs.nih.gov/ntp/about ntp/trpanel/2018/march/tr596peerdraft.pdf. Accessed July 11, 2018.

9. Falcioni L, Bua L, Tibaldi E, Lauriola M, De Angelis L, Gnudi F, Mandrioli D, Manservigi M, Manservisi F, Manzoli I, et al: Report of final results regarding brain and heart tumors in Sprague-Dawley rats exposed from prenatal life until natural death to mobile phone radiofrequency field representative of a $1.8 \mathrm{GHz}$ GSM base station environmental emission. Environ Res 165: 496-503, 2018.

10. Santini R, Santini P, Le Ruz P, Danze JM and Seigne M: Survey study of people living in the vicinity of cellular phone base stations. Electromag Biol Med 22: 41-49, 2003.

11. Abdel-Rassoul G, El-Fateh OA, Salem MA, Michael A, Farahat F, El-Batanouny $M$ and Salem E: Neurobehavioral effects among inhabitants around mobile phone base stations. Neurotoxicology 28: 434-440, 2007.

12. Gómez-Perretta C, Navarro EA, Segura J and Portolés M: Subjective symptoms related to GSM radiation from mobile phone base stations: A cross-sectional study. BMJ Open 3: e003836, 2013.

13. Hutter HP, Moshammer H, Wallner P and Kundi M: Subjective symptoms, sleeping problems, and cognitive performance in subjects living near mobile phone base stations. Occup Environ Med 63: 307-313, 2006.

14. Baliatsas C, Van Kamp I, Lebret E and Rubin GJ: Idiopathic environmental intolerance attributed to electromagnetic fields (IEI-EMF): A systematic review of identifying criteria. BMC Public Health 12: 643, 2012.

15. Singh K, Nagaraj A, Yousuf A, Ganta S, Pareek S and Vishnani P: Effect of electromagnetic radiations from mobile phone base stations on general health and salivary function. J Int Soc Prev Community Dent 6: 54-59, 2016.

16. Buchner $\mathrm{K}$ and Eger $\mathrm{H}$ : Changes of clinically important neurotransmitters under the influence of modulated RF-fields-a long term study under real-life conditions. Umwelt Medizin-Gesellschaft 24: 44-57, 2011. 
17. Eskander EF, Estefan SF and Abd-Rabou AA: How does long term exposure to base stations and mobile phones affect human hormone profiles? Clin Biochem 45: 157-161, 2012.

18. Gandhi G, Kaur G and Nisar U: A cross-sectional case control study on genetic damage in individuals residing in the vicinity of a mobile phone base station. Electromagn Biol Med 34: 344-354, 2015.

19. Zothansiama, Zosangzuali M, Lalramdinpuii M and Jagetia GC: Impact of radiofrequency radiation on DNA damage and antioxidants in peripheral blood lymphocytes of humans residing in the vicinity of mobile phone base stations. Electromagn Biol Med 36: 295-305, 2017.

20. Augner C, Hacker GW, Oberfeld G, Florian M, Hitzl W, Hutter J and Pauser G: Effects of exposure to GSM mobile phone base station signals on salivary cortisol, alpha-amylase, and immunoglobulin A. Biomed Environ Sci 23: 199-207, 2010.

21. Gulati S, Yadav A, Kumar N, Priya K, Aggarwal NK and Gupta R: Phenotypic and genotypic characterization of antioxidant enzyme system in human population exposed to radiation from mobile towers. Mol Cell Biochem 440: 1-9, 2018.

22. Dode AC, Leão MM, Tejo Fde A, Gomes AC, Dode DC, Dode MC, Moreira CW, Condessa VA, Albinatti C and Caiaffa WT: Mortality by neoplasia and cellular telephone base stations in the Belo Horizonte municipality, Minas Gerais state, Brazil. Sci Total Environ 409: 3649-3665, 2011.

23. Khurana VG, Hardell L, Everaert J, Bortkiewicz A, Carlberg M and Ahonen M: Epidemiological evidence for a health risk from mobile phone base stations. Int J Occup Environ Health 16: 263-267, 2010.

24. BioInitiative 2012. A Rationale for Biologically-based Exposure Standards for Low-Intensity Electromagnetic Radiation. Sage C and Carpenter DO (eds). Bioinitiative, 2012. http://www.bioinitiative.org/table-of-contents/. Accessed July 11, 2018.

25. Guidelines for limiting exposure to time-varying electric, magnetic, and electromagnetic fields (up to $300 \mathrm{GHz}$ ) International commission on non-ionizing radiation protection. Health Phys 74: 494-522, 1998.

26. International commission on non-ionizing radiation protection: ICNIRP statement on the "Guidelines for limiting exposure to time-varying electric, magnetic, and electromagnetic fields (up to $300 \mathrm{GHz})^{9}$. Health Phys 97: 257-258, 2009.
27. Le Drean Y, Mahamoud YS, Le Page Y, Habauzit D, Le Quement C, Zhadobov M and Sauleau R: State of knowledge on biological effects at 40-60 GHz. C R Physique 14: 402-411, 2013.

28. Russell CL: $5 \mathrm{G}$ wireless telecommunications expansion: Public health and environmental implications. Environ Res 165: 484-495, 2018.

29. Feldman Y, Puzenko A, Ben Ishai P, Caduff A and Agranat AJ: Human skin as arrays of helical antennas in the millimeter and submillimeter wave range. Phys Rev Lett 100: 128102, 2008.

30. Betzalel N, Ben Ishai P and Feldman Y: The human skin as a sub-THz receiver-Does $5 \mathrm{G}$ pose a danger to it or not? Environ Res 163: 208-216, 2018

31. Soghomoyan D, Trchounian K and Trchounian A: Millimeter waves or extremely high frequency electromagnetic fields in the environment: What are their effects on bacteria? Appl Microbiol Biotechnol 100: 4761-4771, 2016.

32. Cucurachi S, Tamis WL, Vijver MG, Peijnenburg WJ, Bolte JF and de Snoo GR: A review of the ecological effects of radiofrequency electromagnetic fields (RF-EMF). Environ Int 51: 116-140, 2013.

33. Belyaev I: Duration of exposure and dose in assessing nonthermal biological effects of microwaves. In: Dosimetry in Bioelectromagnetics. Markov M (ed). CRC Press, Boca Raton, Florida, chapter 9, 2017.

34. Hedendahl L, Carlberg M and Hardell L: Electromagnetic hypersensitivity-an increasing challenge to the medical profession. Rev Environ Health 30: 209-215, 2015.

35. Belpomme D, Hardell L, Belyaev I, Burgio E and Carpenter DO: Thermal and non-thermal health effects of non-ionizing radiation: An international perspective. Environ Pollut 242: 643-658, 2018.

This work is licensed under a Creative Commons Attribution-NonCommercial-NoDerivatives 4.0 International (CC BY-NC-ND 4.0) License. 